\title{
Quality of Life of Child Labor with a Focus on Developing World: A Sociological Appraisal
}

\author{
Mohammad Taghi Sheykhi* \\ Professor Emeritus of Sociology, Alzahra University, Tehran, Iran \\ *Corresponding author: Mohammad Taghi Sheykhi, Professor Emeritus of Sociology, Alzahra University, Tehran, Iran
}

\section{ARTICLE INFO}

Received: August 08, 2021

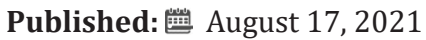

Citation: Mohammad Taghi Sheykhi. Quality of Life of Child Labor with a Focus on Developing World: A Sociological Appraisal. Biomed J Sci \& Tech Res 38(2)2021. BJSTR. MS.ID.006111.

Keywords: Exploitation; Child Labor; Disorder; Potential Effects; Sociology

\begin{abstract}
Child labor creates problems within children now, and for the years to come. Many of the children will face disorders as far as their quality of life is concerned. Many of them would not be able to get sufficient food, adequate schooling, etc. So, the upcoming generations of child labor may also repeat the same cycle in the developing world. The child laborers of the present era are equipped with the cell phones allowing them to travel more and settle down in desired lands alone or with their families. Child laborers easily marry in young ages, and consequently get many children. They easily access to narcotics and commit crimes. Having low quality of life, they transfer it to the next generation as well. Therefore, child labor needs care, supervision and reforms. Supervision on present young families, and use of family planning programs will control the child labor in future. That is what the Third World countries must pay attention to, in order to build healthy generations. In recent years International Labor Organization, Unicef and other UN Departments have intervened to eliminate the present social disorder.
\end{abstract}

\section{Introduction}

Child labor is what is done by the children under the age of 15 , or even 10 in the developing world. It is mainly the result of migration, urbanization and high birth rate. Sociologically speaking, it overall happens due to poverty. Many developing countries are facing it, and take it for granted. The children involved, while having disastrous life, widely affect the next generations. Child labor as exploitation of children was prohibited by legislation worldwide earlier [1] Although laws do not consider all works by children as child labor, exceptions include work by child artists, family duties, supervised training and the like (Labor laws, 2004); Council Directive, 1994) $[2,3]$. With the rise of household income, availability of schools and passage of child labor laws, the incidence rates of child labor fell [3-5]. Child labor is highest in Asia; with over 30 million in India. As the world population will reach above 10 billion by the year 2050, child labor is projected to be on increase in the same way in the developing world [6]. According to the concept of working children; That means working for wages by children under working age (less than 15 years old), and even in some developing societies (10 years old and younger). This phenomenon itself has consequences that are very important from the perspective of sociology and social work. Due to the changes that have occurred in societies over the last half century, following the urbanization of a large part of the population in these societies, as well as the rising cost of living, and on the other hand, due to the increase of children in families, in many societies The evolving phenomenon of child labor has found its appearance, meaning and concept today. Working children, while providing for their daily expenses to some extent, also help their families financially and in condemning the phenomenon of working children, Marx and Engels added more than 160 years ago (1848) that the family was the core of child exploitation, and that this phenomenon should be abolished [7]. Tasks that used to be performed by the family have now been replaced by social work.

It is noteworthy that the exploitation of children took place before and at the beginning of the Industrial Revolution in European societies. The best example of this phenomenon is the Khmer Rouge (1979-1975) in Cambodia, during which children were 
forcibly taken from their families to be raised and exploited by the governing body. While public perceptions of child labor are strongly and seriously negatively charged, it is not clear theoretically how harmful this phenomenon is. For some communities, child labor is a routine; That is, individuals in society and even officials do not react negatively to it, while in industrialized and developed societies, this phenomenon generally has a negative impact, and it is dealt with seriously. In societies where chronic and general poverty prevails, the phenomenon of working children does not seem unusual. While in the West the phenomenon of child labor is an unacceptable face of Third World poverty, child labor is commonplace in many societies. As a result, in Pakistan, for example, many children work full-time outside the family, and do not go to school [8]. While the flow of working children generally occurs worldwide, especially in developing countries in rural areas; That is to say, the quiet and moderate activities carried out by children, which are not very disturbing, are some form of which has been considered by the International Labor Organization (ILO) and many mass media. The phenomenon of working children is more common in rural areas than in urban areas. In developing countries, this phenomenon is generally considered normal, especially in rural areas; That is, places that do not have enough educational centers for such children. Children in these communities under the age of 10 engage in many activities that are usually performed by adults.

Social work searches for and investigates the phenomenon. Child labor under the age of 10 , and in many societies under the age of 15 , has many social, economic, cultural, and biological consequences. This phenomenon in industrialized countries has generally been recognized and stopped for decades. While in developing societies, due to the structure of these societies and the existing constraints, it still continues. In general, among other sciences, there are sociologists and social workers who need to address this issue more.

The consequences of child labor are very complex and contradictory. While this may lead to fewer children "going to school", it may also lead to more work experiences between them, which in itself neutralizes the effects and disadvantages of children's lack of school attendance. There are two views in this regard; Some criticize the separation of children from school and their entry into the labor market, calling it the beginning of many social consequences and deviations, while others justify the separation of children from school in such a way that Such people gain more experience in the labor market. It depends on the social, economic and cultural conditions of the communities. While the phenomenon of working children is common, for example, in a country like Bangladesh, in an industrial society like Japan, it is known to be very unusual and destructive.

\section{Method of Research}

Methodology used in the present article is of qualitative type. In that, various paradigms have been used to find out about the facts regarding pandemics during the history. Qualitative research usually studies people, events or areas in their natural settings. In finding facts for the research, the researcher engaged in careful data collection and thoughtful analysis of what was relevant. In the documentary research applied for the present research, printed and written materials were widely regarded. The research was performed as a qualitative library-type in which the researcher had to refer to the relevant and related sources. In the current research, various documents were thoroughly investigated, and the needful inferences were made.

\section{Challenge Working Children}

Identifying the consequences of child labor is challenging in terms of analysis. Working children cause future generations to face unforeseen challenges and problems. One of the immediate and immediate consequences of this trend is the frequency of marriages at a young age and, consequently, the further growth of the population in these societies, which again provides the basis for working children in the new generation. Thus the cycle of social, economic and cultural anomalies continues. This even jeopardizes social security in a given society. This is generally the case in Southeast Asia and many African and Latin American communities; That is, a situation that leads to street children, criminal gangs, gangsterism, and the like. Therefore, this phenomenon should not be underestimated. The difference in income in families due to the work of their children not only shows the accidental effect, but also the social, economic, cultural effects, etc., while causing problems for the current generation, it also has many effects on the next generation. Therefore, adjusting income in families as a key factor in preventing the increase and incidence of working children. The phenomenon of working children is often specific to countries with poverty in various dimensions; For example, this phenomenon is widespread in African and Latin American countries. The decision to send children to work involves many observable factors; That is, many non-objective factors cause children to deviate from a certain path at the age of 7 to 12 years. In rural areas, they are used to a limited extent, and in contrast, in urban areas, they are widely used; In a way that many dangers threaten them, especially in urban areas. Therefore, the poverty factor itself has an effective role in the emergence of child labor in societies. This phenomenon can be prevented if the family income is improved (Table 1).

Likewise, the consequences of the phenomenon of working children expand over time. Due to the urban life in the present age, working children, especially in urban areas, face many future disorders in their lives. These types of children generally do not have easy access to formal and legal jobs in later years (aged 18 and 
over) due to lack of education and specialization. At the same time, many deviations from the working life of this type of child during their working period before the age of 15 , in some cases, provide them with a bad record, which itself acts as a kind of barrier to their employment in later years. A child who works today is consequently less likely to attend school. He himself may have made less progress in his education in later years. Therefore, as has been proven, children cannot easily pursue their work and education at the same time. Therefore, academic failure is very likely for this type of children. Therefore, welfare organizations, municipalities, etc. should always monitor the child labor community, and, if necessary, provide social assistance, counseling and guidance to them; In a way that separates them from working at a young age, and leads them more to education. Likewise, relevant authorities should always be aware of the oppression, vulnerability, and need to protect children, and prevent / protect them from abnormal and plague-like conditions [9].

Table 1: Picture of the number of working children by age and sex in the early 2000s (number per thousand).

\begin{tabular}{|c|c|c|c|c|c|}
\hline Total Age & Group of Children & $\begin{array}{c}\text { Number of Working } \\
\text { Children }\end{array}$ & Percentage & $\begin{array}{c}\text { Number of Children } \\
\text { in Hard Work }\end{array}$ & Percentage \\
\hline $5-11$ & 838800 & 109700 & 13.1 & 60500 & 7.2 \\
\hline $12-14$ & 360600 & 76000 & 21.1 & 50800 & 14.1 \\
\hline $15-14$ & 1199400 & 186300 & 15.5 & 111300 & 9.3 \\
\hline $15-17$ & 332100 & 59200 & 17.8 & 59200 & 17.8 \\
\hline Boys & 786600 & 132200 & 16.8 & 95700 & 12.2 \\
\hline Girls & 744900 & 113300 & 15.2 & 14800 & 10.5 \\
\hline Total & 1531500 & 245500 & 16 & 170500 & \\
\hline
\end{tabular}

Evaluating such a process itself requires extensive and longterm information. As mentioned, relevant institutions such as welfare organizations or municipalities should be able to collect information about such children. However, in such situations, social workers can play an effective role in correcting these children. Therefore, in relation to the increase in the number of working children, as well as in relation to the increase in the divorce rate in a given society, the number of social workers and the increase in their ratio should also be considered. Studies on work and childhood in 1991-94, and the results obtained among the same people at a young age, in 2004, show that they remained generally agricultural, especially in rural areas, and did not have much social change and mobility. . Many sociologists have conducted this type of research using the follow-up method. In this way, children have studied and studied work for a relatively long period of time, and have achieved remarkable results. It is also noteworthy that children gain more opportunities and development at older ages when they are not in a working position at a young age (around 10 years old and the like). In other words, not being able to work in childhood and subsequently continuing their education usually provides the grounds for their social mobility at a young age and above. Children who do not fit into the global model; That is, they do not choose the path to school, they are abnormally classified and defined [10]. The activities of working children in rural areas are mainly agricultural activities including sowing seeds, processing crops, keeping livestock and the like. The day-to-day activities that children do include things like; Carrying firewood, cooking, house cleaning and the like. Such children typically work more than 16 hours a week, and girls typically work 2.5 hours or more than boys. Hence, the concept of child labor in rural areas, while widely occurring, is itself considered a common phenomenon by rural people in many countries. At the same time, this phenomenon causes the backwardness of these societies in comparison with advanced societies.

\section{Results of the Phenomenon of Working Children}

In examining the potential effects of working children, some results can be noted as follows: The indicators of going to school (primary education and completing at least seven classes) are declining. The World Bank has conducted various studies in this field in South American countries, and finally reached the following results:

1) It is also worth mentioning that not going to school or lack of education of rural children, even in the following years, affects the health status of citizens in urban areas. While many rural children migrate in adulthood, their drop in education at this age causes many harms to and between them.

2) In rural areas, child labor activities in and around agriculture are summarized, and thus children do not have specific rights. It should also be noted that the definition of working children in urban and rural areas is very different from each other. In rural areas, due to the small size of society, limited activities, limited variety of work and the like, children are more observed in agriculture and other related activities, while in urban areas, a variety of different activities of these children can be seen. Likewise, the vulnerability of working children is less in rural areas than in urban areas; Simply because working children 
in these areas, while getting acquainted with agricultural affairs and activities in accordance with local and traditional norms and contracts, are attracted to the same activities and occupations at later ages. Therefore, the vulnerability of such children in rural areas does not seem significant.

3) The process of rural working children itself leads to migration from rural to urban areas; It means providing a kind of social mobility among this type of children. Therefore, the origin of the phenomenon of working children in urban areas is mainly working children in rural areas. This situation is somewhat visible in Iran today and to a large extent in many other less developed societies.

4) It is also worth considering how much the work of children affects their age of marriage. To date, the phenomenon of working children has largely contributed to the low age of marriage. This phenomenon is worth studying from the perspective of sociology and social work, considering the consequences that follow.

5) Early marriage at an early age, which is largely related to the phenomenon of working children, has consequences for women and children, including health risks. Working children, which in turn lead to early marriage, greatly endanger the health of both, especially girls. Issues such as premature fertility, multiple children at an early age, inexperience of mothers and the like, endanger the health of women and girls to a large extent. For this reason, in many societies, fertility and population experts recommend fertility at the age of 18 and older.

6) Working children may be proud of their work in some ways; Because of the help they provide to support the family's food, because of the rental allowance, the scholarships for other siblings, and so on [11].

\section{Objective Effects of Child Labor}

The consequences of such conditions are evidence of the level of education of children in addition to their marriage patterns. Research shows that there is a close relationship between children's work and cases of early marriage at a later age. In many cases, this situation even leads to divorce. At the same time, children's work affects their educational levels (the amount and quality of education among children). Even if children work only 6 hours a week on average; The result in the coming years (over 10 years); Reducing their schooling for about a year reduces them. Therefore, academic failure has a significant relationship with child labor; They even work a few hours a week. Therefore, educational authorities, families and other relevant agencies should, as far as possible, prevent children from entering work with or without pay (wages), so that academic failure is less likely. It should also be noted that the start of 6 hours of work by children per week is even more likely to increase. Income motivation, friends, workplace algebra and other incentives are very effective in increasing children's working hours. Also, if children work about 17 hours a week, children will lose a $20 \%$ chance of completing elementary school. Research shows that there is a link between children's part-time work during the week and how well they succeed in school.

Many social welfare researchers, while examining such cases, recommend a planning system, stating that it is possible to prevent working children under the age of 15 from gaining employment in various economic sectors in society. Such research has recently been conducted by the World Bank in South American countries. While in the West, appropriate and timely legislation separated children from factories, this time owes the number of working children to compulsory education and increased family incomes in those communities (Neuwenhuys: 1996) [12]. As noted, the more children enter the labor market before the age of 15 , the more likely they are to marry at an early age; That is, conditions that lead to higher fertility, the frequency of fertility in adolescence (Teens), before the age of 19 and the like. Therefore, the entry of boys and even girls into the labor market at the age of less than 15 years brings many potential problems and challenges for the following years of these people. The special sexual effects of child labor can also be designed and analyzed. In such circumstances, the negative effects of child labor are more on the academic failure of boys than girls. As mentioned, the abundance and increase of child labor is reflected more in agriculture than in other occupations. In most societies, especially among less developed countries, the phenomenon of working children and its consequences are more focused on boys. While the phenomenon of child labor is present in developing societies, the phenomenon of youth unemployment is also evident in these societies, due not only to high population growth but also to many other causes [13]. The youth unemployment rate is also related to how the economy is growing and the labor market.

However, they generally marry girls at a young age (even less than 15 years old) who seek to enter the labor market while losing their educational opportunities, which in itself has adverse effects in various ways in the present age. At the same time, regardless of the urban and rural nature of the community, children are generally employed in the agricultural sector at an early age. Although this move is considered insignificant in rural communities, sociological analysts consider the development of this phenomenon to be contrary to and an obstacle to development. One of the reasons for the rapid population growth in developing societies, especially in rural areas, is the employment of boys and girls at an early age; That is, the phenomenon that follows early marriage. At the same time, and as far as the conditions of Third World societies are concerned, the work of girls at a young age does not have much of an effect on their entry into the formal labor market in later years. This means 
that in many cases they do not have the opportunity to enter the labor market even in the conditions of entering adulthood and puberty; It means that they get married, raise children, etc. It is also worth mentioning that the entry of girls into the labor market and agricultural affairs at a young age is not very attractive for them; Simply because they remain in activities, sales and the agricultural market after gaining a lot of experience and less in adulthood. While such experiences are very helpful and definite for boys in their adulthood. However, the phenomenon of child labor poses many challenges for both sexes (girls and boys) in both urban and rural areas.

As far as community service is concerned, and from the point of view of this method of assistance, such arrangements should be made so that girls and boys are less out of the ordinary and enter the labor market at an early age. One of these methods in a forward-looking format is to limit the birth rate, especially in rural areas, which is the source of migration. The phenomenon of working children, which in the Third World countries is mainly due to rural poverty and rural migration to urban areas, has its own social, economic, environmental, cultural, health and the like consequences; That is, the current that leads to the phenomenon of working children, especially in rural areas. Resolving such phenomena depends on reducing rural poverty in its various dimensions. To prevent the spread of child labor in the long run, the theory is: when we make a man literate, we make a person literate, but when we make a woman literate, we make a family literate; And that in itself inspires the policy of educating girls. In general, the efficiency and outcome of girls' education help to reform society at its macro level [14]. While the spread of literacy and education, or in other words, access to education itself, causes cultural dissemination [15], its cessation or slowdown leads to cultural and material poverty (non-cultural), and ultimately the emergence of the phenomenon of working children [16].

\section{Conclusion}

Child labor as a public disorder appearing everywhere with high birth rate. It used to exist in the present industrial world in the $19^{\text {th }}$ century. Currently it is available in the developing countries. The best way to avoid it is to apply family planning programs, to increase the educational system, increase industrialization, enact new laws and to enforce work at age plus 15 . To plan an appropriate scheme would also help in controlling child labor in any developing country. International Labor Organization and Unicef which play a determining role in leading the child labor, need to increase their part to manage the problem of child labor. Social work also plays a decisive role to bring about a better reaction between the families and the children who work. However, the existing child labor in developing countries needs to supervise the children concerned not to turn to street children, criminal gangs and the like.

\section{References}

1. (2012) What is Child labor? International Labor Organization.

2. (2004) Labor Laws an Amish Exception. The Economist.

3. (1994) Council Directive 94/33/EC of 22 June 1994 on Child labor

4. (2002) ILO. Every Child Counts: New Global Estimates on Child Labour. IN: Geneva, International Labour Office, Switzerland.

5. Prugl Elisabeth (1999) The Global Construction of Gender, Home-based Work in Political Economy of the $20^{\text {th }}$ Century. Columbia University Press.

6. Hindman H (2009) The World of Child Labor. In: Hindman H (Edt.)., ME Sharpe Publishers, USA

7. (2020) World Population Data Sheet. Population Reference Bureau, Washington DC.

8. Myers WE (1999) Considering Child Labour: Changing Terms, Issues and Actors at International Level. Childhood 6(1): 13-26.

9. Boyden J (1990) Childhood and Policy-makers: A Comparative Perspective on the Globalization of Childhood. In: A James, A Prout (Eds.)., Constructing and Reconstructing Childhood, Falmer London, pp.184-215.

10. Boyden J, J Ennew (1997) Children in Focus: A Manual for Participatory Research with Children, Stockholm: Radda Barnen.

11. Seabrook J (2001) Children of Other Worlds: Exploitation in the Global Market. In: Seabrook J (Edt.)., Pluto, London.

12. Nieuwenhuys 0 (1996) The Paradox of Child Labour and Anthropology. Annual Review of Anthropology 25: 237-251.

13. Ohiiggins N (2001) Youth Unemployment and Employment Policy, Geneva: International Labour Office.

14. King EM, MA Hill (1993) Women's Education in Developing Countries: Barriers, Benefits and Policies. In: King EM, MA Hill (Eds.)., Baltimore, MD: Johns Hopkins University Press, USA.

15. Mayo P (1995) Critical Literacy an Emancipatory Policies: The Work of Paulo Freier. International Journal of Education Development 15(4): 363-379.

16. Marx Karl, F Engles (1989) The Communist Manifesto. In: Marx Karl, F Engles (Eds.)., Verso, London. 
ISSN: 2574-1241

DOI: 10.26717/BJSTR.2021.38.006111

Mohammad Taghi Sheykhi. Biomed J Sci \& Tech Res

(c) (P) This work is licensed under Creative

Submission Link: https://biomedres.us/submit-manuscript.php

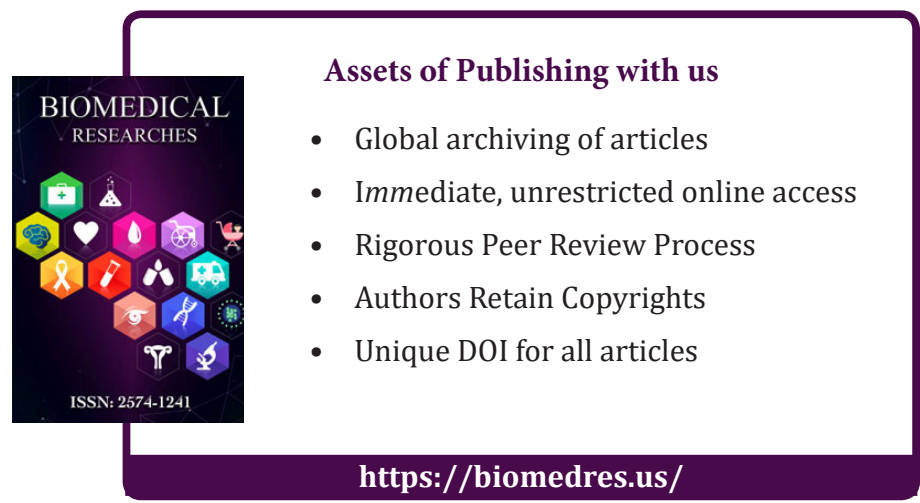

